Federal Reserve Bank of Minneapolis

Research Department Staff Report 294

Revised December 2003

\title{
The 1929 Stock Market: Irving Fisher Was Right*
}

\author{
Ellen R. McGrattan \\ Federal Reserve Bank of Minneapolis \\ and University of Minnesota
}

Edward C. Prescott

Arizona State University

and Federal Reserve Bank of Minneapolis

\begin{abstract}
Many stock market analysts think that in 1929, at the time of the crash, stocks were overvalued. Irving Fisher argued just before the crash that fundamentals were strong and the stock market was undervalued. In this paper, we use growth theory to estimate the fundamental value of corporate equity and compare it to actual stock valuations. Our estimate is based on values of productive corporate capital, both tangible and intangible, and tax rates on corporate income and distributions. The evidence strongly suggests that Fisher was right. Even at the 1929 peak, stocks were undervalued relative to the prediction of theory.
\end{abstract}

*We thank two anonymous referees, the editor, and seminar participants at the Bank of Portugal, the Federal Reserve Bank of Chicago, the SED, MIT, the University of Michigan, the University of Kansas, and the Federal Reserve Bank of Kansas City for their helpful comments. We especially thank Kent Daniel and Lee Ohanian for comments on an earlier draft. We also thank the National Science Foundation for financial support. The views expressed herein are those of the authors and not necessarily those of the Federal Reserve Bank of Minneapolis or the Federal Reserve System. Please address correspondence to: Prescott, Research Department, Federal Reserve Bank of Minneapolis, 90 Hennepin Avenue, Minneapolis, MN, 55401-1804, edward.prescott asu.edu. 


\section{INTRODUCTION}

"Fisher Says Prices of Stocks Are Low," said a headline in the New York Times on October 22, 1929, referring to economist Irving Fisher. Two days later, the stock market crashed, and by the end of November the New York Stock Exchange was down 30 percent from its peak. Fisher had based his statement on strong earnings reports, few industrial disputes, and evidence of high investment in research and development (R\&D) and in other intangible capital. But since market prices fell dramatically so soon after Fisher's statement, most analysts and economic historians concluded that Fisher was wrong: in October 1929 stocks were overvalued.

In this paper, we use modern growth theory to evaluate this conclusion. When stocks of corporations are correctly priced, this theory says, their market value should equal the value of corporations' productive assets, what we will call the fundamental value of corporations. ${ }^{2}$ Productive assets include both tangible and intangible assets. We have direct measures of corporate tangible capital and land and of the tax rates that affect the prices of these assets. We also have measures of profits and the growth rate of the economy which, together with the tangible capital measures, allow us to infer the size of the stock of intangible capital in the corporate sector. We thus can compare the total value of corporate productive assets to the actual market value of corporate stocks at the time of the crash.

Our results support Fisher's view. A conservative estimate of the fundamental value of U.S. corporations in 1929 — which assumes as low a value for intangible capital as observations allow-is at least 21 times the value of after-tax corporate earnings (or 1.9 times gross national product or GNP). The highest estimate of the actual 1929 market value of corporate 
stocks (based on samples of publicly traded stocks) is 19 times the value of after-tax corporate earnings at their peak in 1929 (or 1.67 times GNP). This is strong evidence that Fisher was right: stock prices in the fall of 1929 were a little low relative to fundamental values.

Our estimate of the fundamental value of corporations depends in an important way on the value of intangible capital owned by corporations. Fisher's (1930) conclusion that the stock market was not overvalued in August of 1929 followed from his view that the corporate stock of intangible capital was large. We find that only if the value of corporate intangible capital was zero and the real return on tangible capital was very high by historical standards would the conclusion — reached by De Long and Shleifer (1991) and Rappoport and White (1993) - that the stock market was 30 percent overvalued follow.

The question then is how big is the stock of corporate intangible capital. Fisher (1930) provides many examples of intangible investments, but was limited to anecdotal evidence to make his case that the stock in 1929 was large. We do not have direct measures either, but we use national income statistics to construct an estimate. ${ }^{3}$ We show that even for the smallest level of intangible capital consistent with the data, the stock market in October 1929 was not overvalued relative to the predictions of theory. We estimate that the stock of intangible corporate capital was sizable - at least 60 percent of the stock of tangible corporate capital.

If stock prices were not inflated beyond their fundamental values in October 1929, why did the market crash? Answering that question is not addressed here. But we can point out here that the dramatic decline in stock prices is consistent with monetary policy actions at the time. ${ }^{4}$ Before the crash, the Federal Reserve severely tightened credit to stock investors because, it said, "the unprecedented rise of security prices gave unmistakable evidence of an 


\section{TABLE 1}

Five Estimates of Market Value of All U.S. Corporations on August 30, 1929 Based on Subsets of CORPORATions

\begin{tabular}{lccc}
\hline \hline $\begin{array}{l}\text { Data Source } \\
\text { And Coverage }\end{array}$ & $\begin{array}{c}\text { Market Value of } \\
\text { Companies Covered } \\
(\$ \text { Billions })\end{array}$ & $\begin{array}{c}\text { Price/ } \\
\text { Earnings } \\
\text { Ratio }\end{array}$ & $\begin{array}{c}\text { Estimated Total } \\
\text { Market Value/ } \\
\text { GNP }\end{array}$ \\
\hline Sloan $(1936)$, 135 industrials & 30.8 & 17.5 & 1.54 \\
S\&P, 50 industrials & 26.2 & 18.4 & 1.62 \\
S\&P, 90 composite & 43.3 & 19.0 & 1.67 \\
Fisher $(1930), 45$ industrials & n.a. & 14.1 & 1.24 \\
NYSE, 846 listed & 89.7 & n.a. & 1.24 \\
\hline \hline
\end{tabular}

absorption of the country's credit in speculative security operations to an alarming extent" (Federal Reserve Board, 1929, pp. 1-2). Not long after the crash, the Fed eased credit, and stock prices recovered. ${ }^{5}$ This correlation is worthy of its own detailed investigation.

\section{The Market Value of U.S. Corporations in 1929}

To assess Fisher's view that stock prices in 1929 were low, we first report estimates for the market value of U.S. corporations at the end of August 1929, when stock prices peaked. By "market value" here, we mean the market capitalization of corporations. Data are available for large, representative subsets of U.S. corporations. Here, we use these data to produce a range of estimates for the market value of all U.S. corporations.

Table 1 reports five estimates of the market value of all U.S. corporations at the end of August 1929 relative to GNP in 1929. The first four estimates are obtained by multiplying the ratio of price to after-tax earnings (the $\mathrm{P} / \mathrm{E}$ ratio) for a subset of corporations by the total U.S. after-tax corporate profits of the U.S. economy. All estimates are relative to 1929 
GNP. This is a good way to estimate the total market value as long as the $\mathrm{P} / \mathrm{E}$ ratio for the set of corporations is near the $\mathrm{P} / \mathrm{E}$ ratio for the corporate sector as a whole. Also reported in Table 1 are the market value relative to GNP and the $\mathrm{P} / \mathrm{E}$ ratio for each subset of companies. The fifth estimate in Table 1 is obtained by multiplying the market value of all companies trading on the New York Stock Exchange (NYSE) by a factor that held throughout the post-World War II period; for that period, we have data on the market value of all corporations from the Federal Reserve Board's U.S. flow of funds accounts (Federal Reserve Board, 1945-2000). ${ }^{6}$

In the table, the estimates for the market value of U.S. corporations range between 1.24 and 1.67 times GNP. We think that the best estimate is 1.54 times GNP, which is 17.5 times after-tax corporate earnings. This estimate is based on the study of Sloan (1936). The estimate we will use as the actual market value in our comparison, however, is 1.67 times GNP in 1929, or 19 times the after-tax corporate earnings in 1929, based on the Standard and Poor's (S\&P) composite price index. By using a high estimate of the market value, we are being conservative in evaluating Fisher's view that the stock market was not overvalued just before the crash of 1929 .

We view the estimate of Sloan (1936) as the best because it is the result of a detailed study of 135 industrial corporations, using the best data available at the time. The study was done at the Standard Statistics Company, which later merged with Poor's Publishing to become Standard and Poor's. The corporations studied had fully documented financial histories over the 1922-33 period and were thought to be representative of large companies in business at that time. The study provides detailed income accounts and balance sheets 


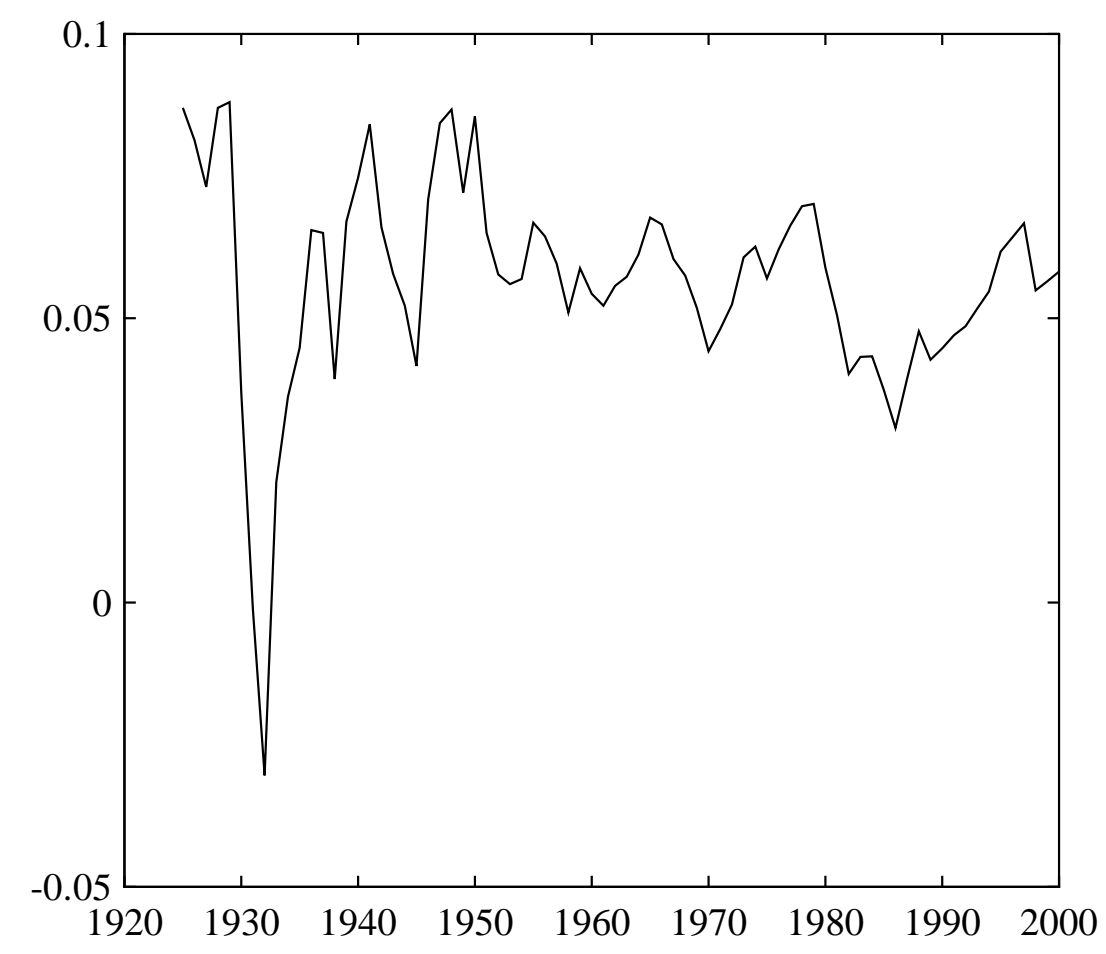

FiguRE 1

The Ratio of After-Tax Corporate Profits to GNP, 1925-2000

for the aggregate and specific details for major industries and major corporations.

At the peak of the stock market in late August and early September 1929, the common stocks of the companies in Sloan's (1936) sample had a market value of $\$ 30.8$ billion. This is about one-third of the market value of all stocks traded on the NYSE at that time. For the year 1929, the after-tax net profits available for the common stock of these companies totaled $\$ 1.76$ billion. If the companies in the Sloan (1936) study are representative of the U.S. economy, then we can use the market value and after-tax profits for these companies to get an estimate of the total value of all corporations.

In Figure 1, we plot the annual ratio of economy-wide after-tax corporate profits to GNP in the United States between 1925 and 2000. Starting in 1929, these data are available in 
the U.S. national income and product accounts (NIPA) published by the BEA in its Survey of Current Business. For earlier years, we must construct our own measures of after-tax corporate profits; we do so by applying the BEA's methodology. (For details of our method, see U.S. Bureau of Economic Analysis (1985) and Table A1 in our appendix.) For 1929, the BEA reports after-tax profits equal to 8.8 percent of GNP. Using the BEA's methodology, we estimate that while profits were high in 1929, this year was not an outlier. After-tax profits in all years from 1925 through 1929 were high by postwar standards.

If we multiply the $\mathrm{P} / \mathrm{E}$ ratio of Sloan (1936), 17.5, by 1929 total NIPA earnings, we get an estimate for the market value of all corporations in late August and early September 1929 of 1.54 times GNP $[=(30.8 / 1.76) \times 0.088]$.

We use the same procedure with companies in the S\&P indices. In Table A2 of our appendix, we provide a list of the 50 companies in the S\&P industrial index, the 20 companies in the S\&P index of railroads, and the 20 companies in the S\&P index of public utilities. The S\&P composite stock index comprises these 90 companies. Along with names, we report on the market capitalization of each company at the end of August 1929 and their net earnings for the year 1929. The market capitalization is computed with data from the University of Chicago's Center for Research on Security Prices (1926-2000) (CRSP). Net earnings are the after-tax profits for common stockholders, which is the sum of common stock dividends plus surplus for the year reported by Moody's Investor Services (1930) and Poor's Publishing Company (1930).

For the 50 industrial companies in the S\&P index, the ratio of the total market capitalization to net earnings is 18.4. Aggregate earnings and this $\mathrm{P} / \mathrm{E}$ ratio imply an estimate for 
the aggregate market capitalization of 1.62 times GNP. This is slightly higher than Sloan's (1936) estimate, which was based on a broader subset of industrial companies.

To compute an estimate of the total market capitalization using all 90 companies in the S\&P composite index, we first construct weights on industrials, railroads, and public utilities using the entire population of companies in the CRSP database for August 1929. We find that the market capitalization of railroads (SIC 4000) in the CRSP population is 12 percent of the total. We find that the market capitalization of public utilities - including electric, gas, and sanitary services (SIC 4900) as well as communications (SIC 4800) and local and interurban passenger transit (SIC 4100)-accounts for 17 percent of the total market capitalization of the CRSP population of companies. The remaining 71 percent is assumed to be in industrials. With weights of 23 percent, 32 percent, and 45 percent on railroads, utilities, and industrials, respectively, we match aggregate market capitalizations with the S\&P subsample.

If we weight market capitalizations and net earnings for the three S\&P categories and then take the ratio, we have a $\mathrm{P} / \mathrm{E}$ ratio of $19.0 .^{7}$ Aggregate earnings and this $\mathrm{P} / \mathrm{E}$ ratio imply an estimate for the aggregate market capitalization of 1.67 times GNP, which is close to that for industrials only.

An estimate of 19.0 for the $\mathrm{P} / \mathrm{E}$ ratio is significantly higher than that reported by Fisher (1930), who cites the Standard Statistics Company as the source for his data. Fisher's Chart 11 shows monthly $\mathrm{P} / \mathrm{E}$ ratios for 45 industrial companies between 1928 and 1929. If we take a 12-month average ending in August 1929, we find the P/E ratio to be 14.1, which is consistent with a total market capitalization of 1.24 times GNP. Unfortunately, there is some ambiguity 


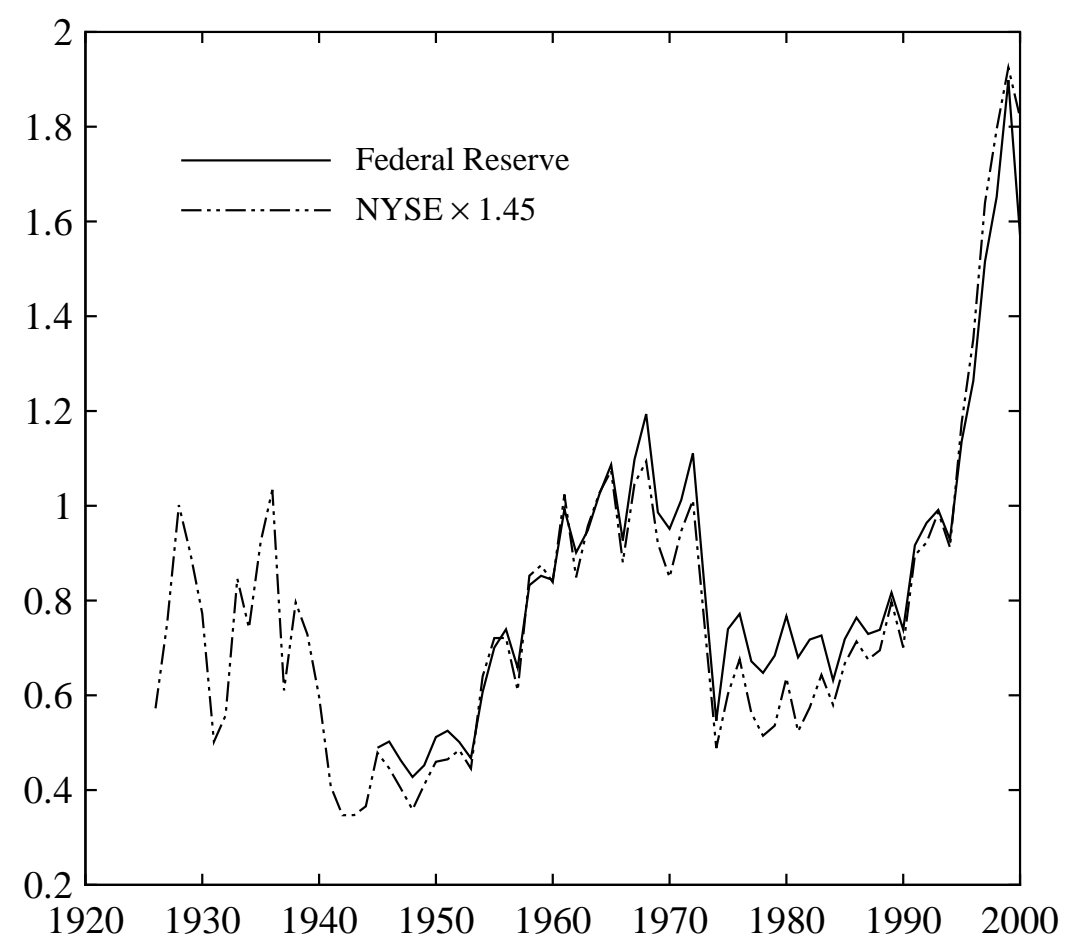

FiguRE 2

Two Measures of the Value of U.S. Corporations, End of Year, Relative to GNP, 1925-2000

as to whether Fisher's numbers are averages of $\mathrm{P} / \mathrm{E}$ ratios or ratios of market capitalization to total earnings.

But there is other evidence on the total market capitalization in 1929 that is consistent with Fisher's estimate. Throughout the postwar period, the market value of all listed shares on the NYSE was very near 69 percent of the total value of all domestic corporations reported by the Federal Reserve Board (1945-2000). We use that statistic to convert NYSE values to data for all U.S. corporations. In Figure 2, we plot the end-of-year market value of all listed shares on the NYSE multiplied by 1.45 (or 1/0.69) for the period 1925-2000 and the end-of-year total value of all domestic companies from the Federal Reserve for the period 1945-2000. The Fed's measure includes the total value of equity of all publicly traded and 
closely held domestic corporations plus the value of their net debt (debt liabilities less debt assets). Before 1974, net debt is a small share of the total value. In 1929, net debt is actually slightly negative, according to the aggregate balance sheet figures reported in the Statistics of Income by the U.S. Internal Revenue Service (1916-99) (IRS); corporations were net creditors. ${ }^{8}$

Figure 2 shows that the market value of NYSE listed shares as a fraction of the total value of all U.S. companies has been remarkably constant. The two time series in Figure 2 are close for the entire post-World War II period-not only on average, but also at peaks and troughs. If we assume that the ratio of NYSE values to the total is about 1.45 in the pre-World War II period as well, we can use the NYSE market capitalization in August 1929 to get an estimate for the total value of all U.S. corporations. The market value of shares for the 846 companies listed on the NYSE in August 1929 was $\$ 89.7$ billion. Thus, our estimate of the total value is about $\$ 130$ billion $(=\$ 89.7 \times 1.45)$, or 1.24 times 1929 GNP. If we assume that aggregate earnings are 8.8 percent of GNP, this implies a $\mathrm{P} / \mathrm{E}$ ratio of 14.1, which is the same as Fisher's (1930) estimate (based on 45 industrial companies).

To summarize, the range of estimates for the market value of all U.S. corporations relative to GNP is from 1.24 to 1.67. We think that Sloan's (1936) estimate of 1.54 is the best, but to be conservative, we will work with the highest estimate of 1.67 times GNP, or 19 times corporate earnings. 


\section{The Fundamental Value of U.S. Corporations in 1929}

Now we need an estimate of the fundamental value of U.S. corporations to compare with the market value just reported. By "fundamental value" here, we mean the value of the underlying productive assets - both tangible and intangible - of the corporate sector. In this section, we construct a lower-bound estimate of the fundamental value of U.S. corporations in August 1929. We show that this estimate exceeds the contemporary market value of U.S. corporations.

If corporate investments are positive and funded out of retained earnings, growth theory says that the fundamental value of a corporation should be equal to

$$
V=\left(1-\tau_{\text {dist }}\right)\left(K_{T}^{\prime}+\left(1-\tau_{\text {prof }}\right) K_{I}^{\prime}\right)
$$

where $K_{T}^{\prime}$ is the end-of-period resource cost of tangible capital, $K_{I}^{\prime}$ is the end-of-period resource cost of intangible capital, $\tau_{\text {dist }}$ is the tax rate on corporate distributions, and $\tau_{\text {prof }}$ is the tax rate on corporate profits. ${ }^{9}$ The price of tangible capital for the shareholders is $\left(1-\tau_{\text {dist }}\right)$, not 1 . The distribution tax affects this price because a dollar reinvested is not taxed, but a dollar distributed is. The price of intangible capital also depends on the corporate profits tax rate because investments in intangible capital are expensed and reduce taxable corporate income.

In the next sections we describe the measures we use for the tax rates and capital stocks. 
TABLE 2

Marginal Tax Rates on U.S. Corporate Income, 1925-29

\begin{tabular}{lcc}
\hline & \multicolumn{2}{c}{$\%$ TAX RATE ON } \\
\cline { 2 - 3 } YEAR & Profits & Dividend \\
\hline 1925 & 15.1 & 9.8 \\
1926 & 15.1 & 10.0 \\
1927 & 15.7 & 10.2 \\
1928 & 14.1 & 11.0 \\
1929 & 13.2 & 10.3 \\
AverAGE & 14.6 & 10.3 \\
\hline \hline
\end{tabular}

3.1. Marginal Tax Rates. We start our computation of the fundamental value of corporations by estimating effective tax rates corporations faced in 1929. The two rates we need are those in equation (1): $\tau_{\text {dist }}$ and $\tau_{\text {prof }}$.

In Table 2, we report marginal tax rates on U.S. corporate profits and dividends for the years 1925-29. These are estimates of the tax paid on an additional dollar of these income types. Calculating the tax rate on profits is straightforward: we take the ratio of the NIPA profits tax liability to the before-tax profits (from Table A1 in the appendix). The tax rate on dividends is more complicated: it's a weighted-average surtax rate on net income computed from data compiled and published by the U.S. Internal Revenue Service (1916-99). In 1929, individual incomes were subject to either the normal tax or a surtax or both. As the names suggest, the normal tax was meant to be the primary source of revenues during nonemergencies. The surtax was used to meet revenue shortfalls typically occurring during wars or crises. The normal tax was not assessed on dividend income, but the surtax was. To compute a single tax rate on dividend income, then, we take a weighted average of 
surtax rates assessed on each net income class, where the weights are fractions of dividend income for each class. (See the appendix for details.)

Both tax rates shown in Table 2 are nearly constant over the 1925-29 period, a period of stable tax policy, and low when compared to rates during and after World War II. The tax rate on corporate profits was on average 14.6 percent, and the tax rate on dividends was on average 10.3 percent.

3.2. Capital Resource Costs. By "resource cost," we mean the tax-unadjusted cost of attaining the asset. In the case of tangible capital, it is reproduction costs. We need estimates of the costs of capital assets, both tangible and intangible. We show that accounting for only tangible capital leads to the conclusion that the stock market in 1929 was close to 30 percent overvalued. Taking account of intangible capital as well-which Fisher (1930) argued was economically important-leads to the opposite conclusion: the stock market was not overvalued. In this way we see that inclusion of intangible capital is crucial in the analysis.

3.2.1. Tangible Corporate Assets. We start with the resource cost of tangible capital, by which we mean things like structures, equipment, and inventories, and add to the BEA measure of that the value of land in the corporate sector. Prior to 1947, inventories are not reported by the BEA so we instead use the value of inventories from balance sheets on corporate tax forms available from the IRS's Statistics of Income. For corporate land, we use nonresidential land from corporate balance sheets reported in Goldsmith (1956) and the Statistics of Income. 


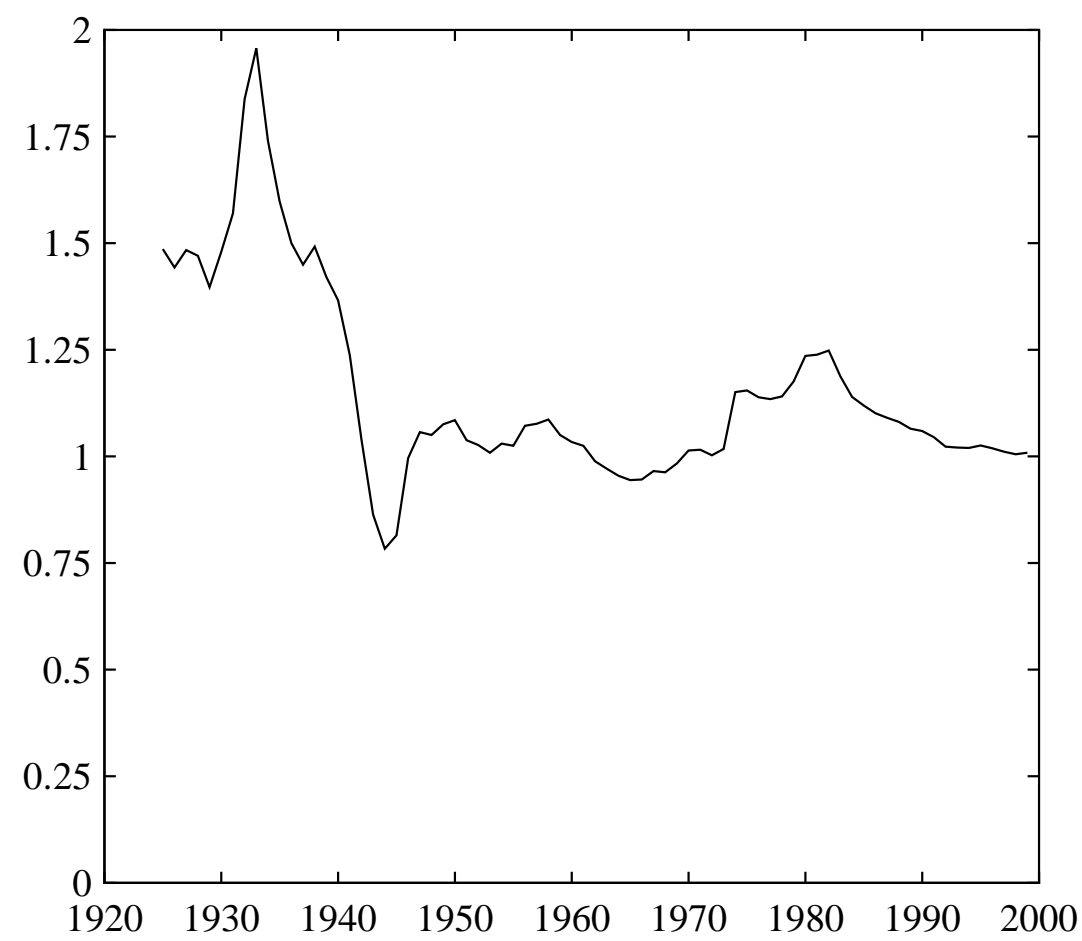

FIGURE 3

The Ratio of U.S. Corporate Tangible Capital and Land to GNP, 1925-2000

In Figure 3, we plot the total resource cost of end-of-period tangible capital plus the value of land, both relative to GNP, for the period 1925-2000. In 1929, the resource cost of total measured, tangible capital, which includes the value of inventories and land, was 1.4 times GNP. ${ }^{10}$ This ratio changed little until the Great Depression period, when output fell more than 30 percent. By postwar standards, 1.4 times GNP is high. But tax rates on capital were much higher in the postwar period.

Using the average tax rates in Table 2 and our formula (1), we compute a fundamental value of 1.26 times GNP $(=(1-.103) \times 1.4)$ for tangible capital alone. Our estimate for the actual market value is $1.67 \mathrm{GNP}$ - 33 percent higher than the fundamental value of tangible capital. 


\subsubsection{Intangible Corporate Assets: The determining factor. De Long and Shleifer}

(1991) and Rappoport and White (1993) both argue that the stock market was significantly overvalued in August 1929 - by as much as 30 percent. ${ }^{11}$ Since our estimate so far includes only corporations' tangible assets, an overvaluation of 30 percent is consistent with predictions of standard growth theory only if the value of intangible assets was negligible. Was it? Fisher (1930) did not think so. He based his view that stock prices were low in 1929 largely on his view that intangible assets were economically important. In this section, we use data that Fisher (1930) did not have to derive a conservative estimate for the value of all intangible capital at the time of the crash. In particular, data from the U.S. national accounts and sources used by the BEA suggest that the value of intangible capital at that time was at least as high as 0.57 times 1929 GNP.

Investments in intangible capital include investments in scientific research and invention, in patent and monopoly rights, and in organizational capital. Fisher (1930) provides some anecdotal evidence that these types of investments were significant in 1929 and were resulting in high economic profits and high stock values.

According to Fisher (1930), industrial research increased significantly after World War I. Scientists from universities and government labs moved to industry jobs in part because their real wages had fallen significantly with wartime inflation. An example Fisher cites is the American Telephone and Telegraph Company which employed 4,000 scientists, "more than any university could equal" [Fisher, 1930, p. 125]. Fisher also cites a study of the National Bureau of Economic Research (NBER), which found that research was being done at 59 percent of the 599 manufacturing firms surveyed. Examples of new inventions reported in 
"almost every day's paper" (p. 127) at the time include rivetless bridges, distilled coal for fuel oil, front-drive cars, pulp made from cornstalk, railroads requiring no overhead wire, artificial silk, and automata with electric eyes. In his fiscal year 1928-29 report, the Commissioner of Patents noted that more patents had been granted during the previous ten years than over the 100 year span 1789-1889 [Fisher, 1930, p. 127]. Implicitly, Fisher's view is that these inventions and patents had led to a large stock of intangible capital and would continue to for some time.

Fisher (1930) also cites "management engineering" (p. 144) as a reason for increased stock values. What Fisher means by this is the introduction of methods for better coordinating of production and sales and for better planning of plant layouts and the subdivision of tasks. Fisher refers to it as the "Fordizing" (p. 142) of business. He cites a study done by the NBER, which concluded that "the greater complexity of business problems and of the organization necessary to cope with them, have forced attention upon better methods of coordinating the plans and the work of specialists and executives" [Fisher, 1930, p. 143]. In other words, these investments enhanced the stock of corporate intangible capital.

Although Fisher had many good examples of intangible capital, he did not have sufficient data to actually measure it. We do. As we show in McGrattan and Prescott (2000), we can estimate the value of intangible capital using data from the U.S. national income and product accounts, available since 1929. In particular, we can infer $K_{I}$ from the following relation between after-tax NIPA profits and corporate capital stocks:

$$
\Pi=i K_{T}+(i-g)\left(1-\tau_{\text {prof }}\right) K_{I}
$$


where $\Pi$ is after-tax NIPA profits, $i$ is the real interest rate, and $g$ is the trend growth rate of real output. ${ }^{12}$ Two assumptions are needed to derive equation (2). First, we assume that the after-tax rate of return for tangible corporate capital is equal to the rate of return for intangible corporate capital and all other types of capital. (This is $i$ in (2).) Otherwise, firms would not be operating in the interest of their owners. Second, we assume that tax policy is unchanging, so that steady-state analysis is appropriate. ${ }^{13}$

To see why (2) holds, consider how the BEA computes NIPA corporate profits. Suppose that the true income from capital in the corporate sector is $r_{T} K_{T}+r_{I} K_{I}$, where $r_{T}$ and $r_{I}$ are rental rates for tangible capital and intangible capital, respectively. If we subtract depreciation allowances for tangible capital, property taxes, and any expenses like R\&D that are related to intangible investment, we have the BEA measure of before-tax corporate profits. This is the income subject to corporate profits tax. Thus, the BEA measure of after-tax corporate profits is

$$
\Pi=\left(1-\tau_{\text {prof }}\right)\left(r_{T} K_{T}+r_{I} K_{I}-\delta_{T} K_{T}-\tau_{\text {prop }} K_{T}-X_{I}\right)
$$

where $\delta_{T}$ is the depreciation rate of tangible capital, $\tau_{\text {prop }}$ is the property tax rate, and $X_{I}=K_{I}^{\prime}-\left(1-\delta_{I}\right) K_{I}$ is intangible investment. In McGrattan and Prescott (2003a), we show that the real after-tax return to tangible investment is $\left(1-\tau_{\text {prof }}\right)\left(r_{T}-\delta_{T}-\tau_{\text {prop }}\right)$, while the real return to intangible investment is $r_{I}-\delta_{I}$. The return on intangible investment is not affected by the corporate income tax rate because intangible investment can be expensed while tangible investment must be capitalized. Equation (2) follows immediately from the fact that both of these returns are equal to $i$, the real interest rate. 
Using (2), we can infer the resource cost of intangible capital using observations on after-tax corporate profits (Figure 1), the resource cost of tangible capital (Figure 3), and the tax rate on corporate profits (Table 2). We also need estimates of the real interest rate (i) and the trend growth rate of the economy $(g)$.

We start with an estimate of the real interest rate $i$. Because of unmeasured intangible investment, we cannot directly infer $i$ from corporate profits and corporate capital. But we can infer $i$ from data for the noncorporate sector, which invests only a negligible amount in scientific research, organizational capital, and other intangibles; most of noncorporate capital is housing, farmland, and consumer durables. To construct $i$, we take the ratio of after-tax noncorporate profits - rental income, proprietors' capital income, net interest, and services of government and consumer capital - to the stock of capital generating these profits. ${ }^{14}$ In 1929, this ratio is 4.73 percent. For the period 1929-2000, the ratio averages 4 percent.

As theory predicts, our estimate for $i$ is similar in magnitude to the average return on long-term debt. ${ }^{15}$ For example, nominal yields for Moody's Aaa-rated corporate bonds averaged 4.7 percent for the period 1925-29. We view this as a good approximation to the real yield since the United States was on a gold standard during this period, and given no trend in the relative price of gold, expectations of inflation should have been near zero. Corporate bonds are fully taxable, so the relevant after-tax rates are somewhat lower. If we use yields on municipal tax-exempt high-grade bonds, which averaged 4.1 percent over 1925-29, our estimates of both the value of intangible capital and the fundamental value of the stock market would be higher. Thus, we view the 4.73 percent return on noncorporate capital as a conservative (that is, high) estimate for the real interest rate. 
Now to the trend growth rate of the economy $(g)$, which is the sum of the growth in population and the growth in technology. Annual population growth had fallen to 1 percent by the late 1920s, and annual technological growth averaged 1.6 percent in the pre-Depression period, according to estimates of Kendrick (1961). Summing these, our estimate for $g$ is 2.6 percent, which is also a conservative estimate. This value is lower than an arithmetic average of growth rates of real GNP in the late 1920s. A larger value for $g$ leads to higher estimates for the value of intangible assets and the fundamental value of the stock market. ${ }^{16}$

We can now compute our estimate for the resource cost of intangible capital:

$$
K_{I}=\frac{\left[\Pi / K_{T}-i\right]}{\left(1-\tau_{\text {prof }}\right)(i-g)} K_{T}=\frac{[.083 / 1.42-.0473]}{(1-.146)(.0473-.026)} K_{T}=.61 K_{T}
$$

The values used in (4) are as follows: 0.146 is the average corporate tax rate in 1925-29; 0.083 is the average ratio of after-tax corporate profits to GNP in $1925-29 ; 0.0473$ is our estimate of the real interest rate based on the noncorporate sector; 1.42 is the average ratio of the resource cost of beginning-of-period tangible capital to GNP in 1926-29; and 0.026 is our estimate of the trend growth rate. The result is a value for the resource cost of intangible capital at least as large as 0.61 times the tangible capital stock. This estimate is consistent with those found for the postwar United States and United Kingdom. (See McGrattan and Prescott (2003a).) The fact that it is sizeable is also consistent with Fisher's evidence.

We deduce from (1) and (4) that very low estimates of intangible capital and very high returns to tangible capital are required for the conclusion that the stock market in 1929 was overvalued. The reason is simple. By (1) and the fact that the value of tangible capital was 
high, a low prediction for the fundamental value of corporate equities requires a low value for intangible capital. With the value of intangible capital low, the return on tangible capital would have had to be extremely high in order to generate corporate profit shares as high as those observed in the 1920s. In the extreme case, with the value of intangibles equal to zero, the real after-tax return on tangible capital has to be 5.9 percent (that is, $\Pi / K_{T}$ in equation (4)), which is much higher than estimates based on national account data.

If we use our estimate in (4), we find that a conservative estimate for the fundamental value of U.S. corporations in 1929 was 1.9 times 1929 GNP, or 21.6 times 1929 after-tax corporate earnings. A fundamental value any lower is not justified by observations on profits, capital stocks, tax rates, growth rates, and interest rates.

With the highest reasonable estimate of the market value of U.S. corporations at the time being 1.67 times GNP, or 19 times corporate earnings, we conclude, as Fisher did, that corporate stocks were not overvalued at the time of the crash. If anything, they were undervalued.

\section{SUMMARY}

In February 1930, Irving Fisher's book The Stock Market Crash-and After was published. In this book, Fisher explains why he believed that stock prices were low in the fall of 1929, placing much emphasis on the value of intangible assets. Galbraith (1955), like many economic historians before and after him, viewed the crash as clear evidence that Fisher was wrong. Fisher's book attracted little attention, according to Galbraith (1955), because "one trouble with being wrong is that it robs the prophet of his audience when he most needs it 
to explain why" (p. 146).

Here, we have examined this period with the aid of tools Fisher did not have: historical data and modern theory. We have, in effect, asked, what level of stock prices is justified by the value of tangible and intangible assets owned by corporations, which we have called the fundamental value. At the start, we set out to quantify by how much the market was overvalued relative to this fundamental value. Theory and data forced us to conclude that it was actually undervalued. Our conservative estimate of the fundamental value of U.S. corporations in 1929 is no less than 21 times corporate earnings (or 1.9 times GNP), whereas a conservative estimate for the market value of U.S. corporate equities in 1929 is no greater than 19 times corporate earnings (or 1.67 times GNP). In other words, with regard to the value of the 1929 stock market, Irving Fisher was right.

But, the primary goal of this study is not to assess the acumen of Fisher. Rather, our goal is to further the development of a theoretical benchmark useful for determining whether the stock market is overvalued or undervalued at a point in time. The value of such a theory is a better basis for investors and policymakers to make informed decisions. 


\section{Appendix: Sources And BaCkground Data}

In this appendix, we describe sources for the data used in the figures and tables of the main text, and we display some detailed data behind some calculations in the text.

\section{Figure 1}

- After-tax corporate profits: See notes for Table A1 for 1925-28; and U.S. Bureau of Economic Analysis (1929-2000), NIPA Table 1.14, for 1929 and after.

- GNP: Romer (1989), Table 2, for period before 1929; and U.S. Bureau of Economic Analysis (1929-2000), NIPA Table 1.9, for 1929 and after.

Figure 2

- Market value of all U.S. corporations: Federal Reserve Board (1945-2000). Add market value of domestic corporations (in the level table of 'Corporate Equities') and the sum of corporate net debt $(=$ total liabilities - total financial assets + corporate equities held directly or in mutual funds) derived from level tables of domestic corporations issuing equity. See McGrattan and Prescott (2003b) for complete details.

- Market value of all listed NYSE companies: U.S. Bureau of Economic Analysis (19322000).

- GNP: See notes to Figure 1.

Figure 3

- Tangible corporate capital: U.S. Bureau of Economic Analysis (1925-2000), fixed asset Table 6.1. 
- Inventories: U.S. Internal Revenue Service (1916-99), corporate balance sheets, before 1946; and U.S. Bureau of Economic Analysis (1929-2000), NIPA Table 5.12, for 1946 and after.

- Land: Goldsmith (1956), Table W-30, before 1946; and U.S. Internal Revenue Service (1916-99), corporate balance sheets, for 1946 and after.

- GNP: See notes to Figure 1.

Table 1

- Market value and earnings of 135 industrials: Sloan (1936, p. 5).

- SEP company list, market values, earnings: See notes for Table A2.

- Price-earnings ratio of 45 industrials: Fisher (1930, p. 86), Chart 11.

- Number of NYSE companies: New York Stock Exchange (1960), historical section.

- Market value of all listed NYSE companies: See notes to Figure 2.

- GNP: See notes to Figure 1.

Table 2

- Tax rate on profits: Rows in Table A1 — "Profits tax liability, NIPA" to "Profits before taxes, NIPA."

- Tax rate on dividends: U.S. Internal Revenue Service (1916-99), basic tables for individual returns (Tables 2 and 7 for years 1925-29) and instructions for 1040, which have the surtax rates. Tax rates are constructed as follows: take the ratio of "Net income" to "Number of returns" for each net income class from Table 2; find the marginal surtax rate for that net income class in the 1040 instructions; multiply the marginal surtax rate for each net income class by the fraction of dividend income earned by that class 
found in Table 7; and add across classes to get a weighted average.

Table A1

- NIPA profits after-tax, 1925-28: All original data sources listed in U.S. Bureau of Economic Analysis (1985), Table 3. Some data are missing because they are not in the public domain. Any missing figures appear in bold and are estimated to be proportional to "Total receipts less total deductions," with the factor of proportionality equal to the 1929 ratio.

Table A2

- Company list: Standard and Poor's (1990, p. 115).

- Market values: CRSP monthly stock database.

- Earnings: Moody's Investor Services (1930) and Poor's Publishing Company (1930).

Other Data Cited in Text

- Population: U.S. Bureau of the Census (1990), Table 16.

- GNP deflator: Romer (1989), Table 2.

- Return on noncorporate capital: McGrattan and Prescott (2003c).

- Bond yields: Federal Reserve Board (1943), Table 128. 
Table A1. Relation of Corporate Profits and Taxes in NIPA and IRS, $1925-29$ (\$ Billions)

\begin{tabular}{|c|c|c|c|c|c|}
\hline & 1925 & 1926 & 1927 & 1928 & 1929 \\
\hline Total receipts less total deductions, IRS & 9.3 & 9.5 & 8.7 & 10.7 & 11.9 \\
\hline Plus: Adjustment for misreporting on income tax returns & .5 & .6 & .5 & .5 & .7 \\
\hline Posttabulation amendments and revisions & .1 & .1 & .1 & .1 & .1 \\
\hline Income of organizations not filing corporation income & .0 & .0 & .0 & .0 & .1 \\
\hline Depletion on domestic minerals & .5 & .6 & .5 & .5 & .6 \\
\hline Adjustment to depreciate expenditures for mining exploration & .1 & .1 & .1 & .1 & .1 \\
\hline State and local corporate profits tax accruals & .1 & .1 & .1 & .1 & .1 \\
\hline Bad debt adjustment & .7 & .7 & .8 & .8 & .9 \\
\hline Net income received from equities in foreign corporations & .2 & .2 & .2 & .2 & .2 \\
\hline \multicolumn{6}{|l|}{ Less: Tax-return measures of: } \\
\hline Gains, net of losses, from sale of property & .5 & .6 & .5 & .6 & .7 \\
\hline Dividends received from domestic corporations & 1.2 & 1.5 & 1.7 & 1.9 & 2.6 \\
\hline Income on equities in foreign corporations and branches & .3 & .3 & .3 & .4 & .4 \\
\hline Costs of trading or issuing corporate securities & .2 & .2 & .2 & .3 & .3 \\
\hline Equals: Profits before taxes, NIPA & 9.3 & 9.3 & 8.3 & 9.9 & 10.6 \\
\hline Federal income and excess profits taxes, IRS & 1.2 & 1.2 & 1.1 & 1.2 & 1.2 \\
\hline Plus: Posttabulation amendments and revisions & .1 & .1 & .1 & .1 & .1 \\
\hline Amounts paid to U.S. Treasury by Federal Reserve banks & .0 & .0 & .0 & .0 & .0 \\
\hline State and local corporate profits tax accruals & .1 & .1 & .1 & .1 & .1 \\
\hline Less: U.S. tax credits claimed for foreign taxes paid & .0 & .0 & .0 & .0 & .0 \\
\hline Equals: Profits tax liability, NIPA & 1.4 & 1.4 & 1.3 & 1.4 & 1.4 \\
\hline Profits after tax, NIPA & 7.9 & 7.9 & 7.0 & 8.5 & 9.2 \\
\hline Profits after tax relative to GNP (\%) & 8.7 & 8.1 & 7.3 & 8.7 & 8.8 \\
\hline
\end{tabular}


Table A2. Market Value at Month-End August 1929 and Net Earnings for Year 1929, All Companies in S\&P Composite Index

\begin{tabular}{|c|c|c|c|}
\hline COMPANIES & $\begin{array}{l}\text { MARKET VALUE } \\
\quad(\$ \text { MILLIONS })\end{array}$ & $\begin{array}{c}\text { Net EARNings } \\
(\$ \text { MILLIONS })\end{array}$ & $\begin{array}{c}\text { PRICE/EARNINGS } \\
\text { RATIO }\end{array}$ \\
\hline \multicolumn{4}{|l|}{50 INDUSTRIALS } \\
\hline General Motors & $3,132.0$ & 236.5 & 13.2 \\
\hline General Electric & $2,852.0$ & 77.3 & 36.9 \\
\hline U.S. Steel & $2,086.1$ & 172.4 & 12.1 \\
\hline Standard Oil of New Jersey & $1,753.1$ & 120.9 & 14.5 \\
\hline Union Carbide \& Carbon & $1,114.1$ & 35.4 & 31.4 \\
\hline Anaconda Copper & $1,060.3$ & 69.1 & 15.3 \\
\hline Woolworth (F.W.) & 967.7 & 35.7 & 27.1 \\
\hline Standard Oil of California & 963.4 & 46.6 & 20.7 \\
\hline Allied Chemical \& Dye & 762.3 & 27.4 & 27.8 \\
\hline Sears, Roebuck & 754.8 & 30.1 & 25.1 \\
\hline Texas Company & 685.7 & 48.3 & 14.2 \\
\hline Radio Corp. & 647.5 & 11.5 & 56.4 \\
\hline Reynolds Tobacco & 603.5 & 32.2 & 18.7 \\
\hline International Nickel & 598.9 & 20.2 & 29.7 \\
\hline International Harvester & 590.2 & 31.3 & 18.8 \\
\hline Eastman Kodak & 483.9 & 21.6 & 22.4 \\
\hline American Radiator \& Standard Sanitary & 478.6 & 19.4 & 24.6 \\
\hline Standard Brands & 476.3 & 17.3 & 27.5 \\
\hline American Can & 440.4 & 19.8 & 22.2 \\
\hline Kresge (S.S.) & 438.7 & 14.8 & 29.6 \\
\hline National Biscuit & 436.0 & 19.7 & 22.1 \\
\hline Kennecott Copper & 418.9 & 52.1 & 8.0 \\
\hline American Tobacco & 394.3 & 27.0 & 14.6 \\
\hline Burroughs Adding Machine & 352.5 & 11.7 & 30.2 \\
\hline General Foods & 340.5 & 19.4 & 17.5 \\
\hline Bethlehem Steel & 331.5 & 35.2 & 9.4 \\
\hline United Fruit & 314.3 & 17.8 & 17.7 \\
\hline Pullman, Inc. & 290.3 & 17.7 & 16.4 \\
\hline Timken Roller Bearing & 261.5 & 14.2 & 18.5 \\
\hline Chrysler Corp. & 300.9 & 21.9 & 13.7 \\
\hline American Smelting \& Refining & 226.9 & 18.3 & 12.4 \\
\hline Westinghouse Air Brake & 203.8 & 8.8 & 23.1 \\
\hline Goodyear Tire \& Rubber & 204.5 & 13.1 & 15.7 \\
\hline National Cash Register & 151.6 & 6.2 & 24.3 \\
\hline Paramount Publix & 146.7 & 15.5 & 9.4 \\
\hline St. Joseph Lead & 138.9 & 7.5 & 18.6 \\
\hline American Locomotive & 94.2 & 4.2 & 22.7 \\
\hline Allis Chalmers & 90.8 & 4.3 & 21.0 \\
\hline Stewart Warner & 84.2 & 6.8 & 12.3 \\
\hline U.S. Rubber & 75.3 & -2.7 & -27.8 \\
\hline International Paper & 74.3 & -4.3 & -17.2 \\
\hline Briggs Manufacturing & 73.6 & 2.4 & 30.3 \\
\hline Twentieth Century-Fox Film Corp. & 65.0 & 8.4 & 7.7 \\
\hline American Sugar Refining & 35.3 & 3.5 & 10.1 \\
\hline Abitibi Paper & 27.5 & 1.9 & 14.1 \\
\hline Endicott Johnson & 26.6 & 2.0 & 13.0 \\
\hline Armour and Co. & 13.5 & 0.8 & 16.5 \\
\hline Cuban American Sugar & 12.8 & 1.1 & 12.0 \\
\hline American Woolen & 6.6 & -4.2 & -1.6 \\
\hline International Mercantile Marine & 3.0 & 2.4 & 1.2 \\
\hline Total, 50 Industrials & $26,085.5$ & $1,420.8$ & 18.4 \\
\hline
\end{tabular}


TABle A2 (CONT.)

\begin{tabular}{|c|c|c|c|}
\hline COMPANiEs & $\begin{array}{l}\text { Market VAlue } \\
\text { (\$ MiLlions) }\end{array}$ & $\begin{array}{c}\text { Net EARNingS } \\
(\$ \text { MILlions })\end{array}$ & $\begin{array}{c}\text { PRICE/EARNINGS } \\
\text { RATIO }\end{array}$ \\
\hline \multicolumn{4}{|l|}{20 RAILROADS } \\
\hline Pennsylvania R.R. & $1,253.0$ & 101.4 & 12.4 \\
\hline New York Central & $1,187.3$ & 78.1 & 15.2 \\
\hline Canadian Pacific & 772.2 & 36.8 & 21.0 \\
\hline Atchison, Topeka \& Santa Fe & 717.2 & 54.8 & 13.1 \\
\hline Union Pacific & 655.8 & 45.3 & 14.5 \\
\hline Southern Pacific & 572.6 & 34.4 & 16.7 \\
\hline Chesapeake \& Ohio & 409.4 & 32.2 & 12.7 \\
\hline Baltimore \& Ohio & 348.0 & 26.4 & 13.2 \\
\hline Norfolk \& Western & 332.2 & 40.9 & 8.1 \\
\hline Great Northern & 311.4 & 25.7 & 12.1 \\
\hline Delaware, Lackawanna \& Western & 276.2 & 13.3 & 20.7 \\
\hline Northern Pacific & 275.9 & 21.8 & 12.7 \\
\hline Southern Railway & 197.6 & 15.1 & 13.1 \\
\hline Illinois Central & 193.0 & 12.4 & 15.6 \\
\hline Reading Co. & 185.7 & 18.3 & 10.1 \\
\hline Louisville \& Nashville & 176.7 & 13.7 & 12.9 \\
\hline Atlantic Coast Line & 161.0 & 19.9 & 8.1 \\
\hline Chicago \& North Western & 158.9 & 14.0 & 11.3 \\
\hline Lehigh Valley & 112.5 & 7.4 & 15.3 \\
\hline New York, Chicago \& St. Louis & 64.8 & 5.2 & 12.4 \\
\hline Total, 20 RAILroads & $8,361.2$ & 617.0 & 13.6 \\
\hline \multicolumn{4}{|l|}{20 Public Utilities } \\
\hline Consolidated Edison of New York & $1,887.0$ & 32.1 & 58.7 \\
\hline United Gas Improvement & $1,098.0$ & 27.6 & 39.7 \\
\hline North American Co. & 942.4 & 27.0 & 34.9 \\
\hline Columbia Gas system & 850.9 & 26.4 & 32.2 \\
\hline International Telephone \& Telegraph & 685.6 & 17.7 & 38.7 \\
\hline Public Service of New Jersey & 532.0 & 22.1 & 24.1 \\
\hline American Power \& Light & 351.9 & 3.3 & 105.4 \\
\hline Detroit Edison & 348.1 & 13.1 & 26.5 \\
\hline Pacific Gas \& Electric & 283.1 & 10.9 & 26.0 \\
\hline American Water Works \& Electric & 281.6 & 6.6 & 42.5 \\
\hline Standard Power \& Light & 245.6 & 7.5 & 32.9 \\
\hline Western Union Telegraph & 233.4 & 17.5 & 13.4 \\
\hline Peoples Gas of Chicago & 209.4 & 6.3 & 33.3 \\
\hline Southern California Edison & 202.3 & 7.7 & 26.1 \\
\hline Pacific Telephone \& Telegraph & 191.5 & 10.7 & 17.9 \\
\hline National Power \& Light & 171.5 & 11.8 & 14.5 \\
\hline Brooklyn Union Gas & 125.5 & 5.6 & 22.6 \\
\hline Brooklyn-Manhattan Transit & 45.8 & 5.0 & 9.1 \\
\hline Twin City Rapid Transit & 9.0 & 1.0 & 8.6 \\
\hline Interborough Rapid Transit & 7.4 & 3.1 & 2.4 \\
\hline Total, 20 Public Utilities & $8,702.1$ & 263.1 & 33.1 \\
\hline Weighted Total, 90 Composite & $16,403.8$ & 863.6 & 19.0 \\
\hline
\end{tabular}




\section{Notes}

${ }^{1}$ We thank two anonymous referees, the editor, and seminar participants at the Bank of Portugal, the Federal Reserve Bank of Chicago, the SED, MIT, the University of Michigan, the University of Kansas, and the Federal Reserve Bank of Kansas City for their helpful comments. We especially thank Kent Daniel and Lee Ohanian for comments on an earlier draft. We also thank the National Science Foundation for financial support. The views expressed herein are those of the authors and not necessarily those of the Federal Reserve Bank of Minneapolis or the Federal Reserve System. Please address correspondence to: Prescott, Research Department, Federal Reserve Bank of Minneapolis, 90 Hennepin Avenue, Minneapolis, MN, 55401-1804, edward.prescott@asu.edu.

${ }^{2}$ Another approach that has been taken to determine whether the stock market in the late 1920s was overvalued is to estimate the present value of future dividends using dividend and interest rate data. With this approach, findings have varied. Compare, for example, Shiller's (1981) Figure 1 with Donaldson and Kamstra's (1996) Figure 7. The reason is that accurately estimating the present value of dividends in this way is difficult, if not impossible.

${ }^{3}$ Hall (2001) has an alternative way to estimate the value of corporate intangible capital, namely, the value of corporate equity and debt less the value of corporate tangible assets. His method cannot be used for determining whether the stock market is overvalued or undervalued as it assumes that the market is correctly valued.

${ }^{4}$ The large decline is also coincident with the speech on October 25 by Attorney General Mitchell, who said he would deal vigorously with antitrust violations. See Bittlingmayer (2002). 
${ }^{5}$ The recovery in stock prices is evidence that a Great Depression was unexpected in 1929 and early 1930. Additional evidence of that is provided by Dominguez, Fair, and Shapiro (1988), who use historical data to forecast future output.

${ }^{6}$ This estimate is essentially the same as that of Jovanovic and Rousseau (2001), who use the same data sources.

${ }^{7}$ Stock prices fell about 30 percent between the end of August and the end of December 1929. Multiplying our estimate of the $\mathrm{P} / \mathrm{E}$ ratio for the end of August by 0.7 gives 13.3 . This is equal to the ratio of the end-of-year market capitalization to 1929 earnings reported by Standard and Poor's (1990).

${ }^{8}$ Thus, any measure that we get of the value of corporate equity in 1929 overstates the total value of corporations, equity plus debt.

${ }^{9}$ For details on the derivation of equation (1), see McGrattan and Prescott (2003a). In McGrattan and Prescott (2003a), we also include the possibility of capital subsidies which are not relevant for 1929 .

${ }^{10} \mathrm{We}$ have left out capital of foreign subsidiaries, which is also not included in BEA measures. But this capital is insignificant in 1929.

${ }^{11}$ Both studies take a very different approach from ours here.

${ }^{12}$ For details on the derivation of equation (2), see McGrattan and Prescott (2000, 2003a).

${ }^{13}$ Support for this assumption is Table 2 and the time series of macro aggregates in Kendrick (1961). 
${ }^{14}$ We estimate that half of net interest payments are intermediate financial services and subtract that half from noncorporate profits.

${ }^{15}$ Due to a modest equity risk premium, our estimate for $i$ is slightly lower than the average return on equity after taxes and costs of diversifying. See McGrattan and Prescott (2003c) for a comparison of asset returns.

${ }^{16}$ We should also note that higher growth rates are associated with higher interest rates since the interest rate is the inverse of the marginal rate of substitution. A very low prediction for intangible capital for the United States in 1929 requires a historically high interest rate and a historically low growth rate. 


\section{REFERENCES}

Bittlingmayer, G., "The 1920's boom, the Great Crash and after," mimeo, University of Kansas, 2002.

Center for Research on Security Prices, U.S. Monthly Stock Database (Chicago: University of Chicago Graduate School of Business, 1926-2000).

De Long, J. B. And A. Shleifer, "The stock market bubble of 1929: Evidence from closed-end mutual funds," Journal of Economic History 51 (1991), 675-700.

Dominguez, K. M., R. C. Fair and M. D. Shapiro, "Forecasting the Depression: Harvard versus Yale," American Economic Review 78 (1988), 595-612.

Donaldson, R. G. And M. Kamstra, "A new dividend forecasting procedure that rejects bubbles in asset prices: The case of 1929's stock crash." The Review of Financial Studies 9 (1996), 333-383.

Federal Reserve Board of Governors, 16th Annual Report of the Federal Reserve (Washington, D.C.: Federal Reserve Board, 1929).

Federal Reserve Board of Governors, Banking and Monetary Statistics, 1914-1941 (Washington, D.C.: Federal Reserve Board, 1943).

Federal Reserve Board of Governors, Flow of Funds Accounts of the United States (Washington, D.C.: Federal Reserve Board, 1945-2000).

Fisher, I., The Stock Market Crash-and After (New York: Macmillan, 1930).

Galbraith, J. K., The Great Crash: 1929 (Boston: Houghton Mifflin, 1955). 
Goldsmith, R. W., A Study of Saving in the United States, Volume III (Princeton, N.J.: Princeton University Press, 1956).

Hall, R. E., "The Stock Market and Capital Accumulation," American Economic Review 91 (2001), 1185-1202.

Jovanovic, B. And P. L. Rousseau, "Liquidity effects in the bond market," Federal Reserve Bank of Chicago Economic Perspectives 25 (2001), 17-35.

Kendrick, J. W., Productivity Trends in the United States (Princeton: Princeton University Press, 1961).

McGrattan, E. R. And E. C. Prescott, "Is the stock market overvalued?" Federal Reserve Bank of Minneapolis Quarterly Review 24 (2000), 20-40.

McGrattan, E. R. and E. C. Prescott, "Taxes, regulations, and the value of U.S. and U.K. corporations," Staff Report 309, Federal Reserve Bank of Minneapolis, October 2003a (http://minneapolisfed.org/research/sr/sr309.html).

McGrattan, E. R. and E. C. Prescott, "Data Appendix: Taxes, regulations, and the value of U.S. and U.K. corporations," Staff Report 309, Federal Reserve Bank of Minneapolis, October 2003b (http://minneapolisfed.org/research/sr/sr309_1.html).

McGrattan, E. R. and E. C. Prescott, "Average debt and equity returns: Puzzling?" American Economic Review, Papers and Proceedings, 93 (2003c), 392-397.

Moody's Investor Services, Moody's Manual of Investments, American and Foreign: Industrial and Public Utility Securities (New York: Moody's Investor Services, 1930).

New York Stock Exchange, NYSE Fact Book (New York: N.Y. Stock Exchange, 1960). 
Poor's Publishing Company, Poor's Railroad and Bank Section (New York: Poor's Publishing, 1930).

Rappoport, P. And E. N. White, "Was there a bubble in the 1929 stock market?" Journal of Economic History 53 (1993), 549-574.

Romer, C. D., "The prewar business cycle reconsidered: New estimates of gross national product, 1869-1908," Journal of Political Economy 97 (1989), 1-37.

Shiller, R. J., "Do stock prices move too much to be justified by subsequent changes in dividends?" American Economic Review 71 (1981), 421-436.

Sloan, L. And Associates, Two Cycles of Corporation Profits (New York: Harper \& Brothers, 1936).

Standard And Poor's, Security Price Index Record (New York: S\&P Corporation, 1990).

U.S. Bureau of the Census, Population and Housing Unit Counts, CPH-2-1 (Washington, D.C.: U.S. Government Printing Office, 1990).

U.S. Bureau of Economic Analysis, Fixed Assets and Consumer Durable Goods. Survey of Current Business (Washington, D.C.: U.S. Government Printing Office, 1925-2000).

U.S. Bureau of Economic Analysis, National Income and Product Accounts, Survey of Current Business (Washington, D.C.: U.S. Government Printing Office, 1929-2000).

U.S. Bureau of Economic Analysis, Survey of Current Business: Annual Supplements (Washington, D.C.: U.S. Government Printing Office, 1932-2000).

U.S. Bureau of Economic Analysis, Corporate Profits: Profits Before Tax, Profits Tax Liability, and Dividends: Methodology Paper (Washington, D.C.: U.S. Government 
Printing Office, 1985).

U.S. Internal Revenue Service, Statistics of Income (Washington, D.C.: U.S. Government Printing Office, 1916-1999). 